\title{
Early Pleistocene formation of the asymmetric east-west pattern of upper water structure in the equatorial Pacific Ocean
}

\author{
JIN HaiYan*, JIAN ZhiMin, CHENG XinRong \& GUO JianQing \\ State Key Laboratory of Marine Geology, Tongji University, Shanghai 200092, China
}

Received December 17, 2010; accepted April 29, 2011

\begin{abstract}
Surface- and subsurface-dwelling planktonic foraminifera from the upper $43 \mathrm{~m}$ of Hole A at the Ocean Drilling Program (ODP) Site 807, which was recovered from the western Pacific warm pool during ODP Leg 130, were analyzed for stable oxygen and carbon isotopes. By comparing these results with data from ODP Site 851 in the eastern equatorial Pacific, this study has reconstructed the paleoceanographic changes in upper ocean waters in the equatorial Pacific since 2.5 Ma. During the period from 1.6-1.4 Ma, the oxygen isotopes of surface and subsurface waters were found to markedly change in the western and eastern equatorial Pacific, further confirming the final formation of the well-defined asymmetric east-west (E-W) pattern at that time. This feature was similar to the zonal temperature gradient (sea surface temperature is higher in the west and lower in the east) and the asymmetric upper water structure (thermocline depth is deeper in the west and shallower in the east) in the modern equatorial Pacific. The zonal gradient change of subsurface water $\delta^{18} \mathrm{O}$ was greater than that of surface water $\delta^{18} \mathrm{O}$, indicating that the formation of the asymmetric E-W pattern in the equatorial Pacific should be much more related to the shoaled thermocline and markedly decreased subsurface water temperature in the eastern equatorial Pacific. Moreover, since $\sim 1.6 \mathrm{Ma}$, the carbon isotopic differences between surface and subsurface waters clearly decreased in the equatorial Pacific, and their long-term eccentricity periods changed from $400 \mathrm{ka}$ to $\sim 500 \mathrm{ka}$, reflecting the reorganization of the ocean carbon reservoir. This probably resulted from the deep water reorganization in the Southern Ocean at that time and its enhanced influence on the tropical Pacific (especially subsurface water). Our study demonstrates that the tropical ocean plays an important role in global climate change.
\end{abstract}

equatorial Pacific, oxygen and carbon isotopes, east-west asymmetric pattern, subsurface water, early Pleistocene

Citation: Jin H Y, Jian Z M, Cheng X R, et al. Early Pleistocene formation of the asymmetric east-west pattern of upper water structure in the equatorial Pacific Ocean. Chinese Sci Bull, 2011, 56: 2251-2257, doi: 10.1007/s11434-011-4547-3

Along with the increasing attention to $\mathrm{El} \mathrm{Niño/Southern}$ Oscillation (ENSO) and monsoonal climate in recent years, it has been widely accepted that the low-latitude tropical ocean plays a key role in global climate systems. This is particularly so in the equatorial Pacific Ocean due to the western Pacific warm pool (WPWP) [1] in the west and the "cold tongue" in the east. In the modern equatorial Pacific, there is a long-term and relatively stable east-west $(\mathrm{E}-\mathrm{W})$ asymmetric pattern of the zonal temperature gradient (sea surface temperature is higher in the west and lower in the east) and the asymmetric upper water structure (thermocline

*Corresponding author (email: jinhy@ tongji.edu.cn) depth is deeper in the west and shallower in the east). Once the asymmetric pattern changed, the tropical climate signals would be transmitted through the exchange of water vapor and heat to the sea in middle and high latitudes and hence influence global climate change [2,3]. Therefore, the time and cause of this asymmetric pattern in the zonal temperature and thermocline gradients for the western and eastern equatorial Pacific has naturally become a topical and relevant research topic for paleoceanographic and paleoclimatic studies of the tropical Pacific. Recently, Wara et al. [4-6] found that the E-W zonal temperature gradient across the tropical Pacific was formed finally at $\sim 1.6 \mathrm{Ma}$, based on the sea surface temperature (SST) reconstruction by the $\mathrm{Mg} / \mathrm{Ca}$ ratios of surface-dwelling planktonic foraminifera. Further 
research has revealed that at $\sim 1.6 \mathrm{Ma}$, in the early Pleistocene, the chemical divide between well-ventilated intermediate water and poorly ventilated deep water was intensified in the Southern Ocean [7]. This reorganization of ocean circulation at high latitudes possibly not only affected the upper water structure and resulted in the E-W asymmetry in the tropical Pacific [8], but also caused a change in the ocean carbon reservoir, such as obscuring the 400 ka cycles in $\delta^{13} \mathrm{C}$ since $1.6 \mathrm{Ma}$ at Ocean Drilling Program (ODP) Site 1143 in the southern South China Sea [9]. However, previous studies of the early Pleistocene E-W asymmetry of the tropical Pacific mainly focused on the SST [4-8], ignoring the changes of subsurface water. In fact, modern oceanographic studies have demonstrated that the abnormal subsurface temperature in the tropical Pacific has a closer relationship to ENSO events $[10,11]$. There is some evidence that during the late Quaternary glacial cycles, the change in tropical subsurface water was even more significant than that of surface water $[12,13]$, showing the particular importance of tropical subsurface water in climate change.

Therefore, this study selected the upper $43 \mathrm{~m}$ of Hole A at ODP Site 807 in the central WPWP for the stable oxygen and carbon isotopic analyses of surface- and subsurfacedwelling planktonic foraminifera. On the basis of the comparison with the records from ODP Site 851 from the eastern equatorial Pacific [14], the paleoceanographic changes of upper ocean waters in the equatorial Pacific since $2.5 \mathrm{Ma}$ were reconstructed for exploring the response of subsurface water changes to the formation of the E-W asymmetric pattern in the tropical Pacific, and hence providing new scientific evidence to better understand the role of the tropical Pacific in global climate change.

\section{Material and methods}

The materials used in this study are from the upper $43 \mathrm{mbsf}$ (meters below sea floor) of Hole A ( $822.9 \mathrm{~m}$ long) at ODP Site $807\left(3^{\circ} 36.42^{\prime} \mathrm{N}\right.$ and $156^{\circ} 37.49^{\prime} \mathrm{E}$, water depth $2804 \mathrm{~m}$, Figure 1), which was recovered from the Ontong-Java Plateau in the western equatorial Pacific during ODP Leg 130. The sediments are well preserved and relatively homogenous in lithology, mainly consisting of light gray-white silty foraminiferal ooze with weak biological disturbance. According to the ODP scientific report for this site [15], the bottom age of the upper $43 \mathrm{~m}$ at Site $807 \mathrm{~A}$ is $\sim 2.5 \mathrm{Ma}$, in the early Quaternary. A total of 860 samples were analyzed in this study, with a sampling interval of $5-10 \mathrm{~cm}$. Oxygen and carbon stable isotope measurements were carried out on surface-dwelling planktonic foraminiferal species Globigerinoides ruber (white, 300-360 $\mu \mathrm{m}$ ) and subsurfacedwelling species Pulleniatina obliquiloculata $(360-440 \mu \mathrm{m})$. Analytical precision referred to the Chinese national carbonate standard GBW04405 and international standard NBS19. The standard errors of $\delta^{18} \mathrm{O}$ and $\delta^{13} \mathrm{C}$ in 2005 were

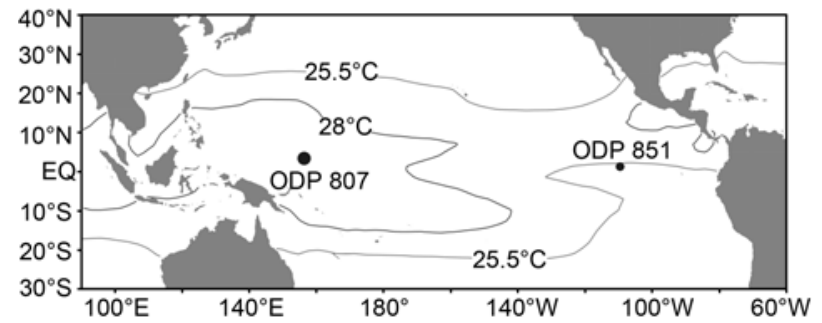

Figure 1 Location of ODP Site 807 . The $28^{\circ} \mathrm{C}$ isotherm marks the boundary of the western Pacific warm pool. ODP Site 851 in the eastern Pacific is also shown in this map.

$0.08 \%$ and $0.06 \%$ (PDB, Pee Dee Belemnite), respectively. The $\delta^{18} \mathrm{O}$ and $\delta^{13} \mathrm{C}$ of G. ruber are marked as $\delta^{18} \mathrm{O}_{G . r u b e r}$ and $\delta{ }^{13} \mathrm{C}_{G \text {. ruber, }}$, whereas those of $P$. obliquiloculata are marked as $\delta^{18} \mathrm{O}_{P . \text { obliquiloculata }}$ and $\delta^{13} \mathrm{C}_{P \text {. obliquiloculata }}$, respectively. All the stable oxygen and carbon isotopic measurements were performed at the State Key Laboratory of Marine Geology at Tongji University.

\section{Chronological framework}

Besides the shipboard bio- and magneto-stratigraphic age points for ODP Site 807A [15], two more planktonic foraminiferal biostratigraphic data, the last appearance datum (LAD) and first appearance datum (FAD) of pink G. ruber at $1.92 \mathrm{mbsf}(120 \mathrm{ka})$ and $6.67 \mathrm{mbsf}$ (400 ka), respectively, were considered in this study. The age model for Site 807A (Figure 2) was built on the basis of the comparison of $\delta^{18} \mathrm{O}_{\text {G. ruber }}$ with the LR04 stack benthic foraminiferal $\delta^{18} \mathrm{O}$ curve [16]. Figure 2 shows that the upper $43 \mathrm{~m}$ part of Site $807 \mathrm{~A}$ recorded the sedimentary history of the last $2.5 \mathrm{Ma}$, including MISs 1-99, with an average sampling time resolution of $\sim 3 \mathrm{ka}$.

\section{Zonal $\delta^{18} \mathrm{O}$ gradient in equatorial Pacific surface and subsurface waters}

Planktonic foraminiferal $\delta^{18} \mathrm{O}$ measurements at ODP Site 807 in the western equatorial Pacific are shown in Figure 3(a). The surface water $\delta^{18} \mathrm{O}_{\text {G.ruber }}$ varied between $-0.68 \%$ and $-2.50 \%$ with an average of $-1.52 \%$, whereas the subsurface water $\delta{ }^{18} \mathrm{O}_{P \text {. obliquiloculata }}$ varied between $0.15 \%$ and $-1.85 \%$ with an average of $-0.96 \%$. According to a modern investigation of planktonic foraminiferal ecology [17], the surface-dwelling species $G$. ruber lives in the upper $50 \mathrm{~m}$ water, while the subsurface-dwelling species P.obliquiloculata is found at a depth range of $100-150 \mathrm{~m}$, in the upper part of thermocline [18]. In this study, the $\delta^{18} \mathrm{O}_{P . \text { obliquiloculata }}$ is $0.56 \%$ heavier than the $\delta^{18} \mathrm{O}_{\text {G. ruber }}$ on average. If $\delta^{18} \mathrm{O}$ gains $0.26 \%$ in accordance with a water temperature decrease of $1^{\circ} \mathrm{C}[19]$, the subsurface water temperature represented by 

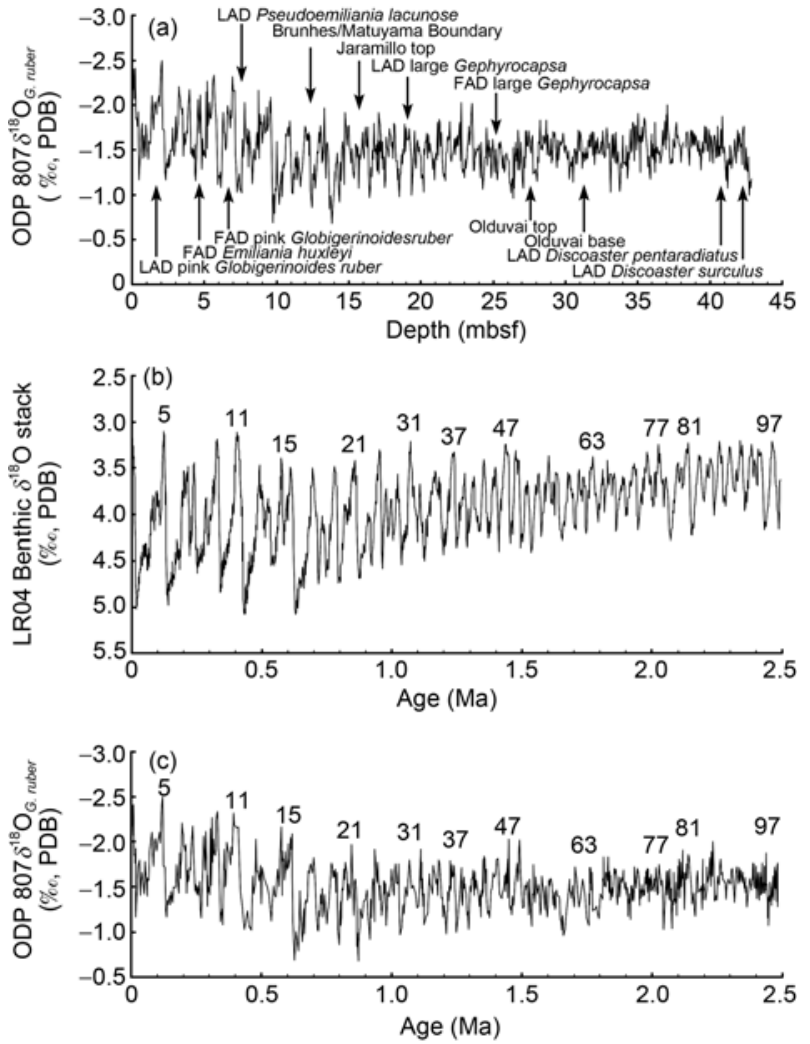

Figure 2 Age model for ODP Site 807. (a) Depth- $\delta^{18} \mathrm{O}$ curve at Site 807; (b) LR04 stack $\delta^{18} \mathrm{O}$ curve of global benthic foraminifera [16]; (c) age$\delta^{18} \mathrm{O}$ curve at Site 807. Arrows in (a) indicate the depths of bio- and magnetostratigraphic data; numbers above the $\delta^{18} \mathrm{O}$ curves in (b) and (c) mark the marine isotopic stage (MIS).

$\delta^{18} \mathrm{O}_{P \text {. obliquiloculata }}$ was $\sim 2^{\circ} \mathrm{C}$ lower than the surface water temperature represented by $\delta^{18} \mathrm{O}_{G \text {.ruber }}$. Based on observational data from the modern ocean (WOA 05 [20]), the water temperature at a depth of $50 \mathrm{~m}$ on the Ontong-Java Plateau in the western Pacific is $28.5-29.0^{\circ} \mathrm{C}$ and at a depth of $100 \mathrm{~m}$ is $26.5-27.0^{\circ} \mathrm{C}$. The temperature difference between them is $2{ }^{\circ} \mathrm{C}$, illustrating that the oxygen isotope results agree with the actual data. Therefore, the stable isotopes of G. ruber and P.obliquiloculata could be used to represent the isotopic variations in surface and subsurface waters, respectively, in the western Pacific.

Since $2.5 \mathrm{Ma}$ (early Quaternary), the surface and subsurface $\delta^{18} \mathrm{O}$ changes at Site 807 in the western equatorial $\mathrm{Pa}$ cific were generally consistent: prior to the "mid-Pleistocene transition [21]" of 0.6-1.2 Ma, the amplitude of $\delta^{18} \mathrm{O}$ fluctuations was relatively small with the dominant 41 ka obliquity cycle; after that, it obviously increased with the dominant $100 \mathrm{ka}$ eccentricity cycle; in between, there was the transitional period for the $\delta^{18} \mathrm{O}$ change. However, recent research has revealed that the "mid-Pleistocene transition" could start from $\sim 1.5 \mathrm{Ma}$ [22], corresponding to the final formation of the zonal SST asymmetric pattern in the equatorial Pacific during the same period [4]. We calculated the $\delta^{18} \mathrm{O}$ differences between subsurface and surface waters
$\left(\Delta \delta^{18} \mathrm{O}_{\text {P.obliquiloculata-G.ruber }}\right)$ at Site 807 and found an increasing trend after 1.4 Ma (Figure 3(b)), which was different from the situation at ODP Site $851\left(2^{\circ} 46^{\prime} \mathrm{N}, 110^{\circ} 34^{\prime} \mathrm{W}\right.$, in a water depth of $3760 \mathrm{~m}$ ) in the eastern equatorial Pacific (at this site, the $\delta^{18} \mathrm{O}$ differences between subsurface and surface waters $\Delta \delta^{18} \mathrm{O}_{\text {G.tumida-G. sacculifer }}$ were calculated from the $\delta^{18} \mathrm{O}$ of subsurface-dwelling planktonic foraminiferal species Globorotalia tumida and surface-dwelling species Globigerinoides sacculifer [14]) (Figure 3(d)). In the western Pacific, the $\delta^{18} \mathrm{O}$ differences between subsurface and surface waters were usually used to indicate the variation of thermocline depth in the upper water column [23,24]. When the surface mixing increases and the thermocline depth becomes deep, the $\delta^{18} \mathrm{O}$ differences decrease, and vice versa. However, in the eastern equatorial Pacific upwelling region, when the upwelling increases, the thermocline depth will become shallower, resulting in a decreased vertical temperature gradient and hence decreased $\delta^{18} \mathrm{O}$ differences between subsurface and surface waters [14], opposite to that in the western Pacific. Therefore, since $1.4 \mathrm{Ma}$, the thermocline depths in both the western and eastern equatorial Pacific have generally experienced a shoaling trend, although they displayed different amplitudes of change; in the eastern Pacific, the most remarkable change for the thermocline shoaling occurred during the period of 1.7-1.4 Ma (Figure 3(d)).

In the equatorial Pacific, estimates of both SST and $\delta^{18} \mathrm{O}$ show that the SST of the WPWP rose slightly after 1.6-1.4 Ma, while the "cold tongue" of the eastern Pacific steadily cooled, showing the end of the long-term El Niño-like conditions that had been present since $5 \mathrm{Ma}$ (the Pliocene) and the final formation of the E-W asymmetric pattern in the equatorial Pacific. This can be proved from the surface water $\delta^{18} \mathrm{O}$ difference $\left(\Delta \delta^{18} \mathrm{O}_{\text {G. sacculifer-G. ruber }}\right)$ between the eastern and western equatorial Pacific. As shown in Figure 4, the subsurface water $\delta^{18} \mathrm{O}$ differences $\left(\Delta \delta^{18} \mathrm{O}_{\text {G. tumida-P.obliquiloculata }}\right)$ between the eastern and western equatorial Pacific were obviously greater than the surface water $\delta^{18} \mathrm{O}$ differences $\left(\Delta \delta{ }^{18} \mathrm{O}_{G \text {. sacculifer-G. ruber }}\right)$ during the last $2.5 \mathrm{Ma}$, indicating that the asymmetric temperature phenomenon had existed for a long time across the equatorial Pacific, as mainly reflected in the subsurface water. After $1.4 \mathrm{Ma}$, both the $\Delta \delta^{18} \mathrm{O}_{\text {G.tumida-P.obliquiloculata }}$ and $\Delta \delta^{18} \mathrm{O}_{\text {G. sacculifer-G. ruber }}$ displayed a continuously increasing trend, reflecting the final formation of the long-term and relatively stable asymmetric pattern of the E-W temperature gradient in the equatorial $\mathrm{Pa}$ cific. We selected $0.6 \mathrm{Ma}$ (the typical $100 \mathrm{ka}$ cycle started to be dominant after the middle Pleistocene climate transition) and 1.4-1.6 Ma (the final formation period of the E-W asymmetric pattern in the equatorial Pacific) as appropriate time boundaries to calculate average values for the periods 0-0.6 Ma, 0.6-1.4 Ma and 1.6-2.5 Ma, and found the subsurface water $\delta^{18} \mathrm{O}$ difference between ODP 851 and ODP $807\left(\Delta \delta{ }^{18} \mathrm{O}_{\text {G. tumida-P. obliquiloculata }}\right)(1.75 \%$, $1.69 \%$ and 
(a)

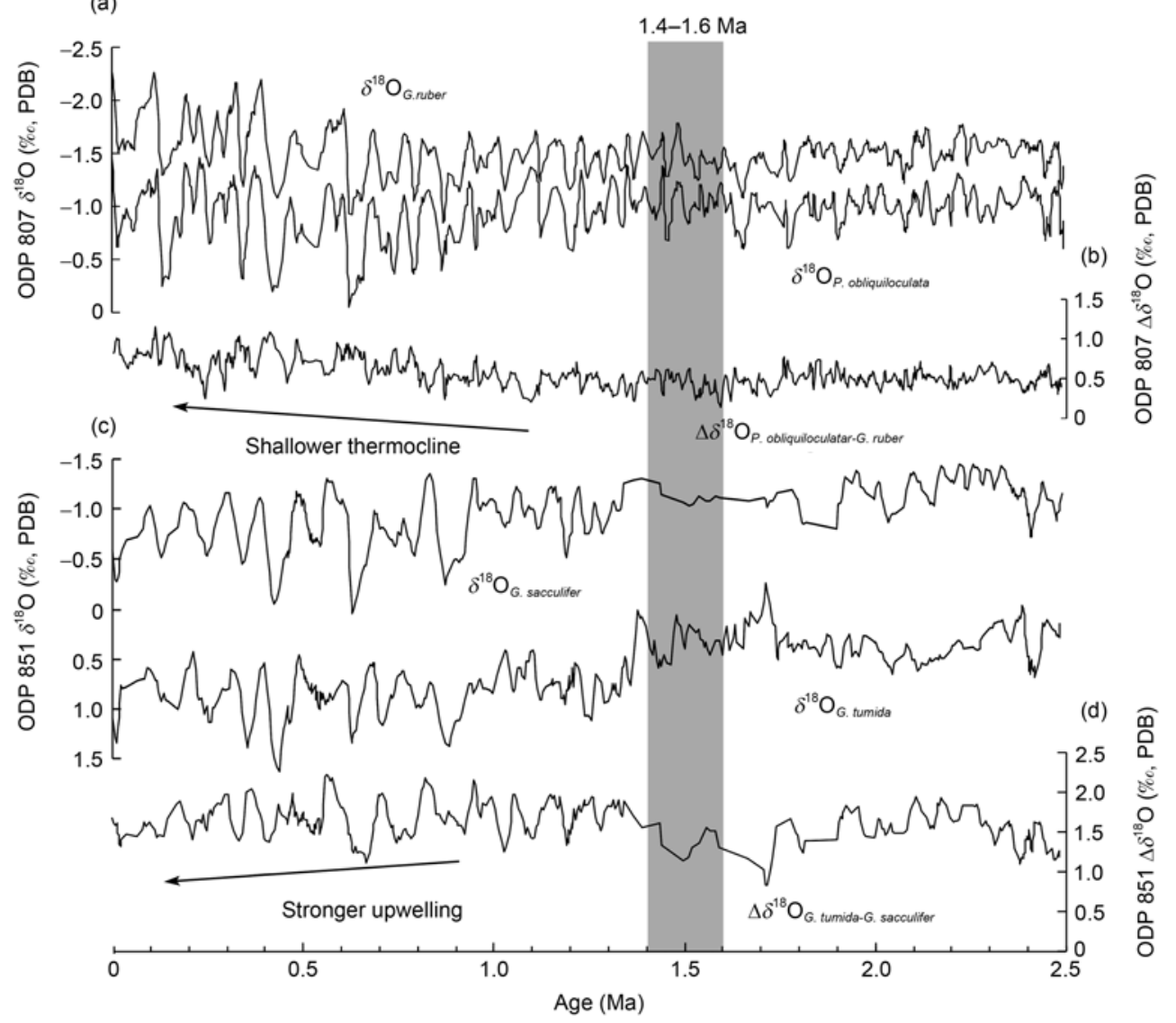

Figure $3 \delta^{18} \mathrm{O}$ variations in the western equatorial Pacific since 2.5 Ma. (a) $\delta^{18} \mathrm{O}$ curves at ODP Site 807 in the western equatorial Pacific; (b) $\delta^{18} \mathrm{O}$ differences $\Delta \delta^{18} \mathrm{O}_{\text {P.obliquiloculata-G. ruber }}$ between subsurface water $\left(\delta^{18} \mathrm{O}_{\text {P.obliquiloculata }}\right)$ and surface water $\left(\delta^{18} \mathrm{O}_{\text {G. ruber }}\right)$ at ODP Site 807; (c) $\delta^{18} \mathrm{O}$ curves at ODP Site 851 in the eastern equatorial Pacific; (d) $\delta^{18} \mathrm{O}$ differences $\Delta \delta^{18} \mathrm{O}_{\text {G. tumida-G. saculifer }}$ between subsurface water $\left(\delta^{18} \mathrm{O}_{\text {G.tumida }}\right)$ and surface water $\left(\delta^{18} \mathrm{O}_{G . \text { sacculifer }}\right)$ at ODP Site 851. All the $\delta^{18} \mathrm{O}$ data were 5-point smoothed at Site 807. Gray bar indicates the period from 1.4-1.6 Ma. Arrows show the general trend of $\delta^{18} \mathrm{O}$ difference between subsurface and surface waters after 1.4 Ma in the western and eastern equatorial Pacific.

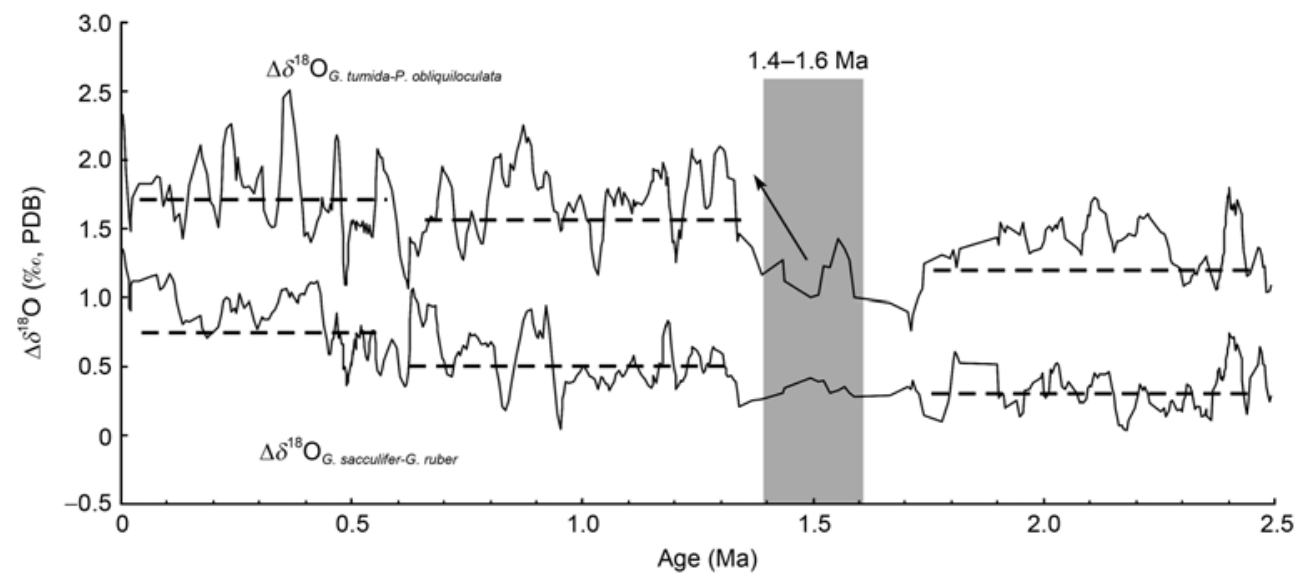

Figure 4 Zonal gradients of surface and subsurface water $\delta^{18} \mathrm{O}$ between ODP Sites 851 and 807 across the equatorial Pacific. All the $\delta^{18} \mathrm{O}$ data were 5-point smoothed. Gray bar indicates the period 1.4-1.6 Ma. Horizontal dashed lines mark the average $\Delta \delta^{18} \mathrm{O}$ values in different time periods. Arrow shows the abrupt change of subsurface $\Delta \delta^{18} \mathrm{O}_{C}$

$1.40 \%$, respectively) were greater than the surface water $\delta^{18} \mathrm{O}$ difference $\Delta \delta^{18} \mathrm{O}_{\text {G. saculifer-G. ruber }}$ at the same time ( $0.85 \%$ o, $0.56 \%$ and $0.34 \%$, respectively). Particularly at $\sim 1.4 \mathrm{Ma}$, the subsurface $\Delta \delta^{18} \mathrm{O}_{\text {G.tumida-P. obliquiloculata }}$ abruptly increased by $1.0 \%$ (corresponding to $\sim 4^{\circ} \mathrm{C}$ temperature increase in the $\mathrm{E}-\mathrm{W}$ subsurface temperature gradient in the 
equatorial Pacific), obviously greater than that of the surface $\Delta \delta^{18} \mathrm{O}_{\text {G. sacculifer-G. ruber }}(\sim 0.5 \%$; Figure 4$)$. This implied that the E-W asymmetric pattern of subsurface water temperature in the equatorial Pacific was also established at 1.6-1.4 Ma (the early Pleistocene) and its change in amplitude was even more significant than that of the surface water.

\section{Discussion of the causes of E-W asymmetric pattern formation in the equatorial Pacific}

Because the sampling resolution for the period from 1.81.4 $\mathrm{Ma}$ at ODP Site 851 in the eastern equatorial Pacific was relatively low (Figure 3(c)), this study combines the results of previous studies [4-6] and takes the early Pleistocene (1.6-1.4 Ma) as the final formation period for the asymmetric E-W pattern in the equatorial Pacific. This was reflected in abruptly increased E-W temperature gradients in both the surface and subsurface waters, and even more so with significant changes in the subsurface water. During the period from 1.6-1.4 Ma, the upwelling strengthened in the eastern equatorial Pacific, which resulted in a shoaled thermocline and markedly decreased subsurface water temperature (around $\sim 1.4 \mathrm{Ma}$, the subsurface $\delta^{18} \mathrm{O}_{P \text {. obliquiloculata }}$ in the western Pacific did not change much but the subsurface $\delta^{18} \mathrm{O}_{\text {G.tumida }}$ in the eastern Pacific became remarkably heavier (Figure 3(a) and (c)). This led to the asymmetric E-W pattern of upper water structure in the equatorial Pacific, with a deep thermocline in the west and shallow one in the east. It is inferred that the asymmetric pattern of the zonal temperature gradient in the equatorial Pacific first occurred in the subsurface water and then led gradually to the formation of the asymmetric pattern in the SST [25] (Figure 4).

Modern ocean observation and numerical modeling research has revealed that the subsurface water in the western equatorial Pacific mainly originates from the "mode water" of the high latitude Southern Ocean, which submerges, flows northward to the low latitude, then to the eastern Pacific as the equatorial counter current where it induces upwelling [26,27]. Because the Southern Ocean is one of the two deep water upwelling zones in the world's oceans, any change in deep water circulation in this area would affect the subsurface and surface waters of the equatorial Pacific and change the vertical structure in the upper water column [28]. Therefore, the formation of the E-W asymmetric temperature pattern in the equatorial Pacific during the period from 1.6-1.4 Ma coincided with the reorganization of ocean circulation in the Southern Ocean [7], and may have possible causal relationships between them [9].

According to the "leaking-Si" hypothesis [29,30], the Si-rich Antarctic mode water would submerge, flow northward and leak into the tropical subsurface water. This could then possibly induce a bloom of diatoms in the tropical ocean, changing the ocean carbon reservoir [9] and reducing the carbon dioxide content in the atmosphere. Actually, the early Pleistocene asymmetric pattern of the zonal temperature gradient across the equatorial Pacific can also be reflected in the carbon isotope records of planktonic foraminifera. As shown in Figure 5, the carbon isotopic differences between planktonic foraminiferal surface-dwelling species $\left(\delta{ }^{13} \mathrm{C}_{G \text {. ruber }}\right.$ and $\left.\delta{ }^{13} \mathrm{C}_{G \text {. sacculifer }}\right)$ and subsurfacedwelling species $\left(\delta^{13} \mathrm{C}_{P \text {. obliquiloculata }}\right.$ and $\left.\delta^{13} \mathrm{C}_{\text {G.tumida }}\right)$ in both the eastern and western equatorial Pacific obviously decreased after 1.6-1.4 Ma, implying that the carbon reservoir of upper water in the tropical Pacific significantly changed. Particularly, six carbon isotope maximum events, $\delta^{13} \mathrm{C}_{\max }-\mathrm{I}$ to $\delta^{13} \mathrm{C}_{\max }-\mathrm{VI}$, since $2.5 \mathrm{Ma}$ can be clearly recognized in Figure 5, with a $400 \mathrm{ka}$ cycle prior to $1.6 \mathrm{Ma}$ and an average $\sim 500 \mathrm{ka}$ cycle after 1.6 Ma. This phenomenon is present in the global oceans including the southern South China Sea [9,31]. After 1.6 Ma, due to the effect of high latitude ice cover in the northern hemisphere, the regular $\sim 400 \mathrm{ka}$ "heart beating" cycle of the ocean carbon reservoir [32] was disturbed and the so-called "cardiac arrhythmia" phenomenon appeared. This probably indicated that the earth climate system was controlled by polar ice volume instead of solar radiation since that time [9].

Therefore, the final formation of the asymmetric E-W pattern of upper water structure in the equatorial Pacific during the early Pleistocene period (1.6 to $1.4 \mathrm{Ma}$ ) may be related to the reorganization of deep circulation in the Southern Ocean, and its main change could happen in the subsurface water. Once the E-W asymmetric pattern formed in the equatorial Pacific, the long-term permanent El Niño-like condition since $5 \mathrm{Ma}$ (Pliocene) was closed in the equatorial Pacific [4-6]. The tropical climate signals would be transmitted through the exchange of water vapor to the sea in middle and high latitudes, affect the ocean carbon reservoir, and hence play an important role in global climate change.

\section{Conclusions}

(1) The oxygen isotopic difference $\Delta \delta^{18} \mathrm{O}_{P}$. obliquiloculata-G. ruber between planktonic foraminiferal subsurface-dwelling species ( $P$. obliquiloculata) and surface-dwelling species $(G$. ruber) showed a generally increasing trend after 1.6-1.4 Ma at ODP Site 807 in the western equatorial Pacific. By comparison with paleoceanographic records from ODP Site 851 in the eastern equatorial Pacific, this study confirmed that the asymmetric E-W pattern of upper water structure, like the modern zonal temperature gradient, was finally formed during the period from 1.6-1.4 Ma in the equatorial Pacific. The change in the E-W gradient in the subsurface water $\delta^{18} \mathrm{O}$ across the equatorial Pacific was greater than that in the surface water $\delta^{18} \mathrm{O}$, indicating that the asymmetric pattern of the zonal temperature gradient across the equatorial 


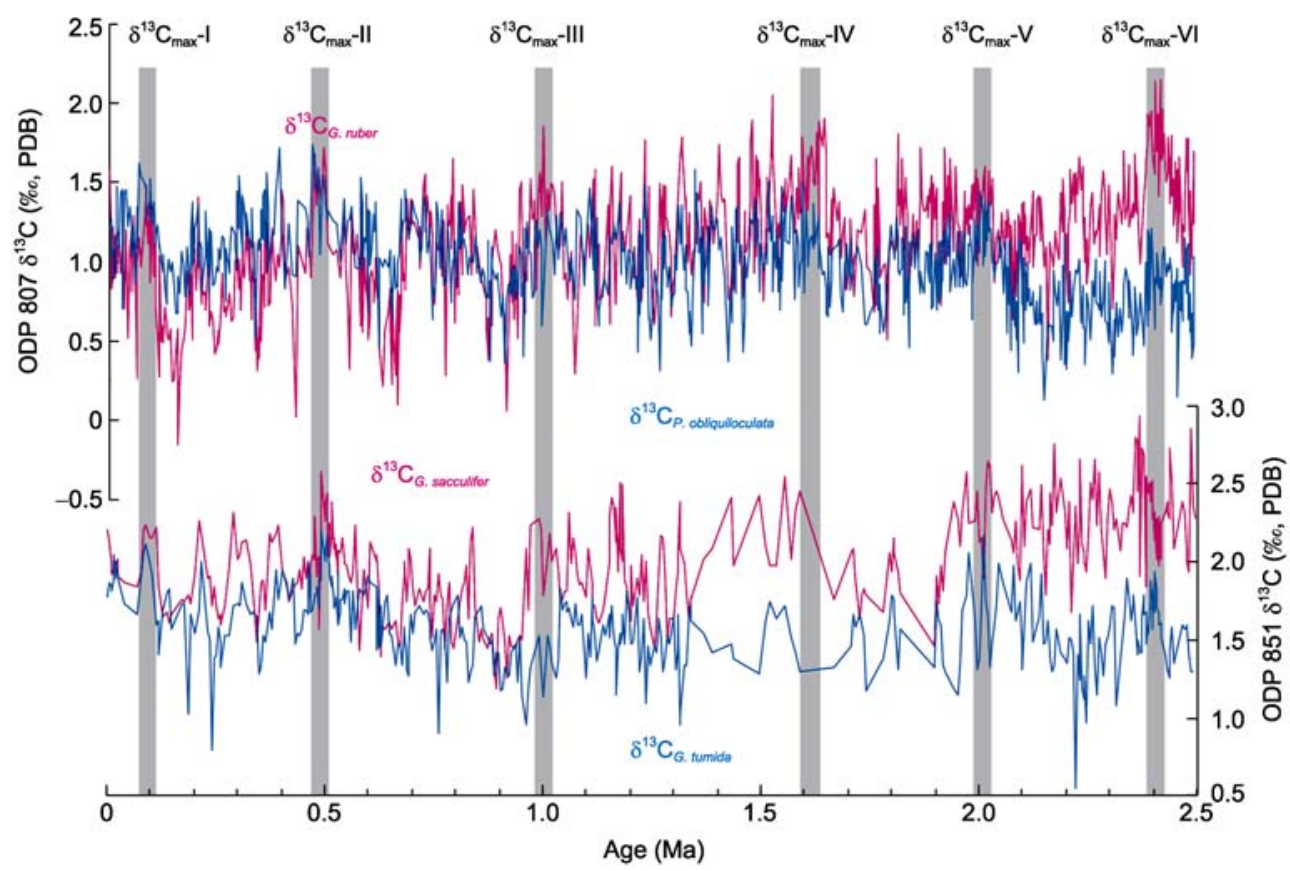

Figure 5 Variations of carbon isotopes in the equatorial Pacific since $2.5 \mathrm{Ma}$. Red and blue curves show the $\delta^{13} \mathrm{C}$ of surface and subsurface water, respectively. Gray bars mark the carbon isotopic maximum events from $\delta^{13} \mathrm{C}_{\max }-\mathrm{I}$ to $\delta^{13} \mathrm{C}_{\max }-\mathrm{VI}$.

Pacific first took place in the subsurface water and then gradually led to the formation of the asymmetric pattern in SST.

(2) Since 1.6-1.4 Ma (early Pleistocene), the planktonic foraminiferal carbon isotopic differences between subsurface- and surface-dwelling species markedly decreased in both the eastern and western equatorial Pacific, and their long-term eccentricity periods changed from 400 ka to $~ 500$ $\mathrm{ka}$, reflecting major changes in the ocean carbon reservoir. Therefore, the formation of the asymmetric E-W pattern in the equatorial Pacific during the period from 1.6-1.4 Ma coincided with the reorganization of ocean circulation in the Southern Ocean, and there may possibly be a causal relationship between them. This would change the ocean carbon reservoir and thus influence changes in global climate.

We thank two anonymous reviewers for constructive reviews, as well as the shipboard scientists of Ocean Drilling Program (ODP) Leg 130 for providing the samples used in this study. This work was supported by the National Natural Science Foundation of China (40806020), the National Basic Research Program of China (2007CB815901), the Doctoral Program Foundation of Institutions of Higher Education of China (200802471034) and the China Ocean Mineral Resources R\&D Association (DY11501-2-3).

1 Yan X H, Hou C, Zheng Q. Temperature and size variabilities of the Western Pacific Warm Pool. Science, 1992, 58: 1643-1645

2 Cane M. A role for the tropical Pacific. Science, 1998, 282: 59-61

3 Webster P, Magana V, Palmer T, et al. Monsoon: process, predictability and the prospects for prediction. J Geophys Res, 1998, 103: $14451-14510$

4 Wara M W, Ravelo A C, Delaney M L. Permanent El Niño-like conditions during the Pliocene warm period. Science, 2005, 309: 758-761
5 Lawrence K T, Liu Z, Herbert T D. Evolution of the Eastern Tropical Pacific through Plio-Pleistocene glaciation. Science, 2006, 312: 79-83

6 Ravelo A C, Andreasen D H, Lyle M, et al. Regional climate shifts caused by gradual global cooling in the Pliocene epoch. Nature, 2004, 429: 263-267

7 Hodell D A, Venz-Curtis K A. Late Neogene history of deepwater ventilation in the Southern Ocean. Geochem Geophys Geosys, 2006, 7: Q09001, doi: 10.1029/2005GC001211

8 Fedorov A V, Dekens P S, McCarthy M, et al. The Pliocene paradox (mechanisms for a permanent El Niño). Science, 2006, 312: 1485-1489

9 Wang P X, Tian J, Lourens L J. Obscuring of long eccentricity cyclicity in Pleistocene oceanic carbon isotope records. Earth Planet Sci Lett, 2010, 290: 319-330

10 McPhaden M J, Busalacchi A J, Cheney R, et al. The tropical oceanglobal atmosphere observing system: A decade of progress. J Geophys Res, 1998, 103: 14169-14240

11 Li C, Mu M. El Niño occurrence and subsurface ocean temperature anomalies in the Pacific warm pool. Chin J Atmos Sci, 1999, 23: 513-521

$12 \mathrm{Xu}$ J, Holbourn A, Kuhnt W, et al. Changes in the thermocline structure of the Indonesian outflow during Terminations I and II. Earth Planet Sci Lett, 2008, 273: 152-162

13 An Y, Jian Z M. Pulleniatina Minimum Event during the last deglaciation in the southern South China Sea. Chinese Sci Bull, 2009, 54: 4514-4519

14 Ravelo A C, Shackleton N J. Evidence for surface-water circulation changes at Site 851 in the eastern tropical Pacific ocean. Proceedings of the Ocean Drilling Program, Scientific Results, 1995, 138: 503-514

15 Prentice M L, Friez J K, Simonds G G, et al. Neogene trends in planktonic foraminifer $\delta^{18} \mathrm{O}$ from site 807: Implications for global ice volume and western equatorial Pacific sea surface temperatures. Proceedings of the Ocean Drilling Program, Scientific Results, 1993, 130: 281-283, 295-298

16 Lisiecki L E, Raymo M E. A Pliocene-Pleistocene stack of 57 globally distributed benthic $\delta^{18} \mathrm{O}$ records. Paleoceanography, 2005, 20, PA1003, doi: 10.1029/2004PA001071

17 Bé A W H. An Ecological, Zoogeographic and Taxonomic Review of Recent Planktonic Foraminifera. In: Ramssy A T S, ed. London: Academic Press, 1977. 1-100 
18 Cléroux C, Cortijo E, Duplessy J C, et al. Deep-dwelling foraminifera as thermocline temperature recorders. Geochem Geophys Geosys, 2007, 8, doi: 10.1029/2006GC001474

19 Moore T C Jr, Pisias N G, Keigwin L D Jr. Cenozoic Variability of Oxygen Isotopes in Benthic Foraminifera. Washington D C: National Academy Press, 1982. 172-182

20 Locarnini R A, Mishonov A V, Antonov J I, et al. World Ocean Atlas 2005, Temperature. In: Levitus S, ed. NOAA Atlas NESDIS 61. Washington, D C: U.S. Government Printing Office, 2006. 1-182

21 Berger W H, Bickert T, Jansen E, et al. The central mystery of the Quaternary Ice Age. Oceanus, 1993, 36: 53-56

22 Rutherford S, Hondt S D. Early onset and tropical forcing of 100000-year Pleistocene glacial cycles. Nature, 2000, 408: 72-75

23 Jian Z M, Wang P X, Saito Y, et al. Holocene variability of the Kuroshio Current in the Okinawa Trough, northwestern Pacific Ocean. Earth Planet Sci Lett, 2000, 184: 305-319

24 Tian J, Wang P X, Chen R, et al. Quaternary upper ocean thermal gradient variations in the South China Sea: Implications for East Asian monsoon climate. Paleoceanography, 2005, 20: PA4007, doi: 10.1029/2004 PA001115

25 Medina-Elizalde M, Lea D W, Fantle M S. Implications of seawater
$\mathrm{Mg} / \mathrm{Ca}$ variability for Plio-Pleistocene tropical climate reconstruction. Earth Planet Sci Lett, 2008, 269: 585-595

$26 \mathrm{Gu}$ D, Philander S G H. Interdecadal climate fluctuations that depend on exchanges between the tropics and the extratropics. Science, 1997, 275: 805-807

27 Pedlosky J. A History of Thermocline Theory. In: Jochum M, Murtugudde R. New York: Springer, 2006. 139-152

28 Sarmiento J L, Gruber N, Brzezinski M A, et al. High-latitude controls of thermocline nutrients and low latitude biological productivity. Nature, 2003, 427: 56-60

29 Anderson R F, Chase Z, Fleischer M Q, et al. The Southern Ocean's biological pump during the Last Glacial Maximum. Deep Sea Res Part II, 2002, 49: 1909-1938

30 Crosta X, Beucher C, Pahnke K, et al. Silicic acid leakage from the Southern Ocean: Opposing effects of nutrient uptake and oceanic circulation. Geophys Res Lett, 2007, 34: L13601, doi: 10.1029/2006GL029083

31 Wang P X, Tian J, Cheng X R, et al. Major Pleistocene stages in a carbon perspective: The South China Sea record and its global comparison. Paleoceanography, 2004, 19, doi: 10.1029/2003PA000991

32 Pälike H, Norris R D, Herrle J O, et al. The heartbeat of the Oligocene Climate System. Science, 2006, 314: 1894-1898

Open Access This article is distributed under the terms of the Creative Commons Attribution License which permits any use, distribution, and reproduction in any medium, provided the original author(s) and source are credited. 